\title{
SOSIALISASI ZOHO FORM SEBAGAI SARANA SURVEI ONLINE BAGI MAHASISWA
}

\author{
Yogi Yunefri ${ }^{1}$, Fajrizal ${ }^{2}$, Elvira Asril ${ }^{3}$ \\ ${ }^{1}$ Universitas Lancang Kuning, Pekanbaru, Indonesia \\ 2,3Universitas Lancang Kuning, Pekanbaru, Indonesia \\ email: yogiyunefri@unilak.ac.id ${ }^{1}$, fajrizal@unilak.ac.id ${ }^{2}$, elvira@unilak.ac.id ${ }^{3}$
}

\begin{abstract}
Abstrak: Pembuatan dan penyebaran kuesioner secara konvensional berdampak dalam pengumpulan data dan penyelesaian skripsi menjadi lebih lama. Sementara di sisi yang lain mahasiswa harus dapat menyelesaikan kuliah tepat waktu. Ketepatan mahasiswa menyelesaikan kuliah berimbas juga pada akreditasi program studi dan perguruan tinggi. Tujuan pelaksanaan pengabdian kepada masyarakat untuk menumbuhkan pengetahuan dan wawasan agar mahasiswa dapat mempergunakan aplikasi Zoho Form dalam pembuatan kuesioner dan pengumpulan data karya ilmiah secara online. Mengingat masih banyaknya mahasiswa Fakultas Ilmu Budaya Universitas Lancang Kuning yang belum mengetahui cara pembuatan kuesioner menggunakan aplikasi Zoho Form. Selama ini mahasiswa masih menggunakan cara konvensional dalam pembuatan dan penyebaran kuesioner. Pelatihan diikuti oleh mahasiswa semester akhir Fakultas Ilmu Budaya Universitas Lancang Kuning sebanyak 10 peserta. Pelaksanaan pengabdian kepada masyarakat menggunakan pendekatan ceramah, bimbingan praktek secara langsung dan diskusi agar peserta dapat memahami materi yang disampaikan. Berdasarkan hasil Pretest dan Posttest memperlihatkan bahwa setelah seminar semua mahasiswa dapat memahami penggunaan aplikasi Zoho Form untuk pembuatan kuesioner dan pengumpulan data karya ilmiah.
\end{abstract}

Kata Kunci: Survei, Aplikasi Zoho Form, Angket, Kuesioner

\begin{abstract}
The conventional creation and distribution of questionnaires results in longer data collection and completion. While on the other hand, students must be able to finish college on time. The accuracy of students completing college has an impact on study accreditation programs and universities. The purpose of community service is to grow knowledge and insight so that students can practice the Zoho Form application in making and collecting scientific work data online. There are still many students of the Faculty of Cultural Sciences, Lancang Kuning University who do not know how to make a questionnaire using the Zoho Form application. So far, students are still using conventional methods in making and distributing questionnaires. The training was attended by 10 students in the final semester of the Faculty of Cultural Sciences, Lancang Kuning University. The implementation of community service uses a lecture approach, direct practical guidance and discussions so that participants can understand the material presented. Based on the results of the Pretest and Posttest, after the seminar all students can understand the use of the Zoho Form application for making scientific work data collection and collection.
\end{abstract}

Keywords: Surveys, Zoho From Applications, Questionnaires.

\section{Pendahuluan}

Skripsi merupakan karya ilmiah yang ditulis oleh mahasiswa program sarjana pada akhir masa studinya berdasarkan hasil penelitian, atau kajian kepustakaan, atau pengembangan terhadap suatu masalah yang dilakukan secara seksama (Roellyana \& Ratih, 2016). Skripsi disusun sebagai syarat kelulusan bagi mahasiswa untuk mendapatkan gelar sarjana sesuai dengan bidang yang ditekuni (Asmawan, 2017). Dalam penyusunan karya ilmiah dibutuhkan data yang sesuai dengan topik karya ilmiah tersebut. Salah satu teknik pengumpulan data adalah dengan melakukan survei. Survei merupakan instrumen penelitian ilmiah untuk mengumpulkan data primer agar mendapatkan 
feedback dari responden dengan cara memberikan kuesioner (Muchlis, Christian \& Sari, 2019). Kuesioner merupakan sekumpulan pertanyaan yang digunakan untuk memperoleh informasi dari responden terkait dengan pribadinya maupun hal-hal lain yang terkait dengan materi penelitian (Nugroho,2018).

Pembuatan dan penyebaran kuesioner dalam penulisan karya ilmiah di kalangan mahasiswa semester akhir sering dilakukan, terutama untuk pengambilan data skripsi pada bidang disiplin ilmu sosial. Pembuatan dan penyebaran kuesioner secara konvensional berdampak pada durasi waktu yang lama dalam pengumpulan data, sehingga pada gilirannya akan menyebabkan penyelesaian skripsi menjadi lebih lama. Sementara di sisi yang lain mahasiswa harus dapat menyelesaikan kuliah tepat waktu agar tidak lagi terbebani dengan biaya kuliah. Selain itu juga ketepatan mahasiswa menyelesaikan kuliah berimbas juga pada akreditasi program studi dan perguruan tinggi.

Berdasarkan hasil survei yang dilakukan terhadap mahasiswa semester akhir dan pihak Fakultas Ilmu Budaya Universitas Lancang Kuning menyatakan bahwa persoalan yang dihadapi saat ini adalah pengumpulan data yang tidak efektif dan efisien. Ketidakefektifan dan ketidakefisienan terutama dengan banyaknya penggandaan hardcopy dari kuesioner yang harus dilakukan, waktu yang lebih lama, dan membutuhkan biaya yang lebih besar.

Perkembangan teknologi yang terintegrasi dengan internet memiliki peran yang penting dan membantu dalam pengumpulan data kuesioner. Banyak aplikasi-aplikasi yang dapat digunakan untuk mendukung dalam pembuatan dan penyebaran kuesioner berbasis online dan gratis. Salah satu software yang mudah diakses, gratis digunakan, sederhana dalam pengoperasian dan cukup baik untuk digunakan sebagai media untuk pembuatan dan penyebaran kuesioner adalah Zoho Form (Batubara \& Noor, 2017). Penggunaan aplikasi Zoho Form akan membawa perubahan dari konvensional ke paperless culture (Yuniarti \& Hartat, 2020). Paperless culture merupakan suatu bentuk budaya baru dalam pembuatan kuesioner di era teknologi informasi yang tidak menggunakan kertas di dalam pembuatan dan penyebaran kuesioner, serta tabulasi data dilakukan secara otomatis dan online (Batubara,2016).

Aplikasi Zoho Form merupakan aplikasi yang berbasis web sehingga memudahkan pengguna untuk mengaksesnya dengan menggunakan komputer, laptop tanpa mengenal tempat dan waktu selama ada jaringan internet. Zoho Form banyak digunakan di dalam dunia pendidikan dan penelitian. Manfaat Zoho Form di dunia pendidikan seperti melaksanakan ujian online, survei penilaian terhadap guru/dosen, pendaftaran siswa/mahasiswa baru, absensi online (Sianipar, 2019).

Berikut beberapa penelitian atau pengabdian kepada masyarakat yang menggunakan aplikasi Zoho Form Pelatihan model pembelajaran jarak jauh berbasis Zoho Forms sebagai media pembelajaran terhadap 30 guru dari berbagai daerah di Indonesia. bertujuan untuk meningkatkan wawasan dan keterampilan guru dalam menggunakan Aplikasi Zoho Form tersebut sebagai media pembelajaran jarak jauh. Pelatihan dilakukan dalam bentuk tutorial dan diskusi tentang langkah-langkah untuk membuat media kuis online menggunakan aplikasi Survei. Hasil kegiatan menunjukkan bahwa peserta pelatihan sudah memahami prinsip-prinsip menciptakan kuis dan mampu menciptakan kuis online menggunakan aplikasi Survei. Pemanfaatan Aplikasi Survei dalam Monitoring Kegiatan Kuliah pada Program Studi Fisika Universitas Negeri Makassar bertujuan untuk mengumpulkan data kegiatan perkuliahan per pekan untuk kepentingan analisis kesesuaian materi kuliah dan rencana pembelajaran semester, memantau tingkat kehadiran dan keterlaksanaan perkuliahan sesuai jadwal. Aplikasi Survei ini dipilih karena 
tergolong sebagai aplikasi open source, digunakan secara online, dan kesederhanaan dalam perancangan dan penggunaannya. Aplikasi Survei yang dirancang digunakan oleh dosen sebagai pengampu mata kuliah dan mahasiswa sebagai peserta kuliah. Dalam riset pengembangan ini, hasil yang diperoleh berupa form isian, hasil input data setiap pengguna, dan basis data hasil input dari seluruh pengguna. Analisis terhadap data yang diperoleh merupakan luaran tambahan yang dibahas secara terpisah (Ihsan, Tiwow \& Saleh, 2020).

Sosialisasi Pembuatan Soal Melalui aplikasi survei Dalam Meningkatkan Kompetensi Guru PAI dilaksanakan dalam bentuk sosialisasi dan pelatihan. Target yang ingin dicapai dalam kegiatan ini adalah terwujudnya keterampilan guru PAI memanfaatkan Aplikasi Survei dalam melaksanakan evaluasi. Pihak-pihak yang terlibat dalam kegiatan ini adalah pengurus AGPAII (Asosiasi Guru Pendidikan Agama Islam Indonesia) sebagai panitia dan narasumber, team ahli sebagai narasumber utama dari Universitas Muhammadiyah Sumatera Barat, guru PAI yang tergabung dalam AGPAII sebagai objek. Hasil kegiatan ini adalah peserta yang mengikuti kegiatan pelatihan sebanyak 142 orang, narasumber melakukan sosialisasi dengan metode ceramah dan memberikan pelatihan melalui simulasi, serta peserta dapat membuat soal melalui aplikasi survei (Ritonga dkk, 2020). Penggunaan media aplikasi survei dalam evaluasi pembelajaran Bahasa Arab Maharah Kitabah sangat praktis. Selain sangat praktis, penggunaan platform aplikasi survei juga memudahkan guru dalam memberikan nilai kepada siswa, karena aplikasi survei juga memiliki fitur quiz yang dapat memberi skor pada jawaban atas pertanyaan yang diberikan (Amalia, 2019). Penelitian pengembangan tes diagnostik menggunakan aplikasi survei materi momentum dan impuls untuk siswa SMA bertujuan untuk mengembangkan tes diagnostik dengan aplikasi survei yang digunakan untuk mengeksplorasi kesalahpahaman siswa tentang momentum dan impuls di Sekolah Menengah Atas. Penelitian ini menerapkan desain Research and Development (R \& D). Tes diagnostik dikembangkan berdasarkan konsep awal siswa tentang momentum dan dorongan yang diambil dari beberapa studi sebelumnya dari Departemen Pendidikan Fisika UNTAN. Populasi penelitian ini dilakukan pada siswa SMA negeri di Pontianak. Sampel ini penelitian adalah 97 siswa dari kelas XI. Penelitian ini memberikan 15 item tes diagnostic pertanyaan yang dibagi menjadi dua kategori; sedang dan mudah. Pertanyaan moderat adalah 13 item sementara yang mudah bernomor 2 item. Tingkat validitas konten penelitian ini 0.70 . Kemudian, keandalan menunjukkan 0,715. Berdasarkan hasil validasi di atas dengan indeks Aiken 1 dan beberapa data respons siswa, aplikasi formulir google dapat dikategorikan sebagai kategori tinggi (87,6\%). Jadi, aplikasi survei dapat digunakan untuk pertanyaan tes diagnostik (Maulidiansyah, 2018). Dari uraian diatas, untuk menumbuhkan minat mahasiswa mengenai pemanfaatan Zoho Form dalam penulisan karya ilmiah diperlukan sebuah aktivitas dalam bentuk seminar dan praktek langsung penggunaan aplikasi zoho form.

Adapun tujuan kegiatan Pengabdian Kepada masyarakat dalam bentuk seminar pemanfaatan Zoho Form dalam bidang penelitian adalah untuk menumbuhkan pengetahuan dan wawasan agar mahasiswa dapat mempraktekan aplikasi Zoho Form dalam pembuatan kuesioner dan pengumpulan data karya ilmiah secara online.

\section{Metode}

Kegiatan pengabdian kepada masyarakat ini menggunakan metode ceramah, praktek, dan diskusi. Metode ceramah dimaksudkan untuk memberikan pengetahuan 
sejauh mana zoho form dapat dimanfaatkan untuk mendukung pengambilan data dalam bentuk kuesioner. Praktek dilaksanakan secara singkat dengan mempraktekkan pembuatan kuesioner dalam zoho form. Sedangkan diskusi dilakukan untuk melihat sejauh mana antusias peserta dalam kegiatan ini. Kegiatan pengabdian kepada masyarakat ini dilaksanakan pada tanggal 05 Juli 2021 menggunakan aplikasi zoom dan dilakukan secara daring di masa pandemi covid-19. Adapun peserta yang hadir dalam kegiatan ini berjumlah 10 orang mahasiswa semester akhir.

Agar pelaksanaan kegiatan pengabdian kepada masyarakat berjalan sesuai dengan tujuan yang diharapkan, maka dilakukan survei lokasi. Survei lokasi ini dilakukan untuk dapat menganalisis situasi target pengabdian, diskusi dengan ketua UP2M dalam penentuan tema dan bentuk kegiatan pengabdian kepada masyarakat. Dalam pelaksanaan kegiatan ini diawali dengan pemberian pretest kepada peserta mengenai pengetahuan awal tentang manfaat Zoho Form dalam pembuatan kuesioner dan pengumpulan data untuk karya ilmiah. Setelah itu dilanjutkan dengan penyampaian materi mengenai pemanfaatan Zoho Form dalam mendukung pengumpulan data karya ilmiah mahasiswa. Penyampaian materi ini dilakukan baik secara teori maupun praktek singkat dengan mengambil contoh karya ilmiah dari peserta seminar, yaitu tingkat kepuasan pelanggan terhadap pelayanan kasir di Indomaret. Penyampaian materi diselingi juga dengan diskusi. Pada tahap ini diakhiri dengan pemberian beberapa pertanyaan (Post Test) untuk mengetahui tingkat pemahaman peserta setelah materi disampaikan. Hasil jawaban kuesioner akan dievaluasi sebagai masukan untuk melakukan pengabdian kepada masyarakat di waktu mendatang.

\section{Hasil dan Pembahasan}

Pengabdian yang dilakukan meliputi dua tahapan, yaitu tahapan pertama melakukan sosialisasi tentang perkembangan teknologi yang bisa digunakan dalam melakukan survei, kemudian tahapan kedua melakukan pelatihan cara penggunaan aplikasi Zoho Form. Berikut akan dipaparkan mengenai hasil yang telah dicapai pertiap tahapannya :

a) Tahapan Pertama :

Tahap ini menjelaskan tentang bagaimana perkembangan teknologi dalam melakukan survei sehingga dalam penelitian mahasiswa dengan mudah mendapatkan informasi.

b) Tahapan Kedua :

Pada tahapan ini siswa kita ajarkan menggunakan aplikasi Zoho Form untuk menunjang kegiatan pengabdian ini, pelaksanaan kegiatan tersebut dilaksanakan pada:

Hari / Tanggal : Senin, 05 Juni 2021

Pukul $\quad: 10.00 \mathrm{~s} / \mathrm{d}$ Selesai

Tempat : : Menggunakan Aplikasi Zoom

Berikut ini adalah langkah-langkah dalam menggunakan aplikasi Zoho Form:

\section{1) Login ke dashboard Zoho Form}

Kunjungi website zoho.com, Kemudian klik Login atau Sign up jika belum memiliki akun Zoho

\section{2) Mulai membuat Formulir}

Untuk mulai membuat form online Anda bisa memilih menu Form, kemudian klik tombol "Create New Form". 


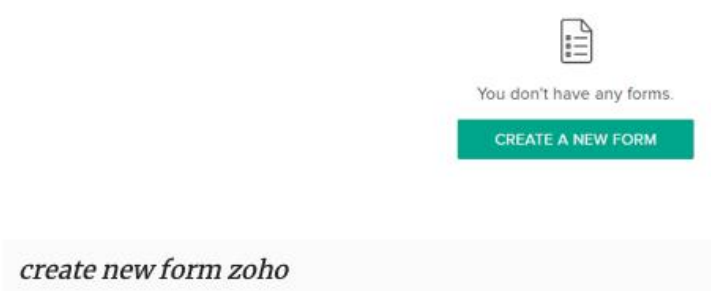

Gambar 1. Membuat Form Baru

Anda akan diberikan dua pilihan, apakah ingin menggunakan template form dari Zoho atau membuat sendiri dari awal. Untuk tutorial kali ini kita akan membuat form dari awal dengan memilih "Blank Form/Template".

\section{3) Isi Bagian Judul dan Deskripsi}

Selanjutnya, Anda bisa mengisi bagian judul form dan deskripsi sesuai tujuan. Jika sudah selesai, bisa langsung klik tombol Create.

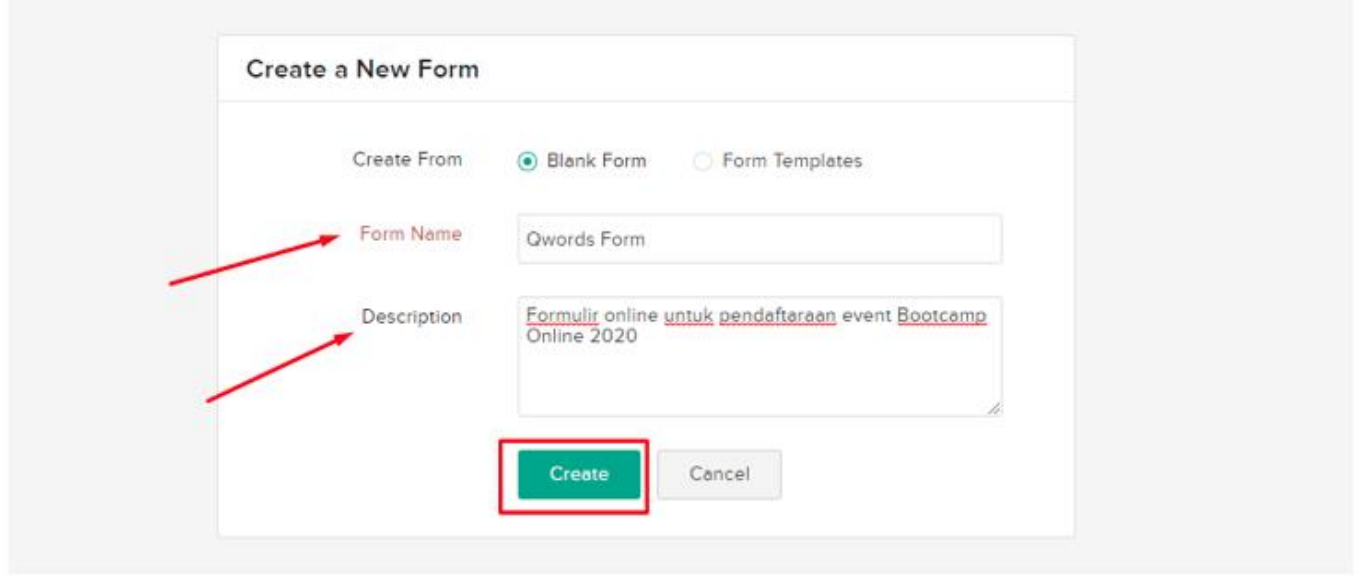

Gambar 2. Pengisian Judul Form

\section{4) Desain Konten Formulir Online}

Bagian ini menjadi tahap paling menarik ketika membuat formulir online. Pasalnya, Anda bisa mengeksplore fitur dan fungsi apa saja yang ditawarkan oleh penyedia layanan formulir online.

\section{5) Menyimpan Hasil Formulir Online.}

Setelah merancang halaman formulir online, jangan lupa untuk menyimpan hasil pekerjaan. Caranya Anda tinggal klik tombol Save di bagian pojok kanan atas.

\section{6) Membagikan Formulir Online}

Langkah terakhir dalam proses pembuatan formulir online adalah membagikan dengan calon audiens. Untuk membagikan form yang sudah dibuat di Zoho, Anda bisa memilih tombol "Access Form" yang ada di pojok kanan atas, kemudian mengcopy URL di halaman browser.

Luaran yang dicapai dari pengabdian ini adalah mahasiswa dapat memanfaatkan Zoho Form sebagai alat survey dalam penelitian mahasiswa sehingga informasi yang 
dibutuhkan dalam penelitian tersebut dapat diperoleh dengan mudah. Pada pengabdian ini Tim IbM melakukan pengukuran tingkat pemahaman peserta menggunakan Kuesioner, hasil kuesioner tersebut menunjukkan bahwa:

1) Zoho Form sebagai media dalam membantu untuk melakukan Survei.

Tabel 1. Perhitungan Survai

\begin{tabular}{|l|c|c|c|c|}
\hline & Frequency & Percent & $\begin{array}{c}\text { Valid } \\
\text { Percent }\end{array}$ & $\begin{array}{c}\text { Cumulative } \\
\text { Percent }\end{array}$ \\
\hline Valid Sangat Tidak Setuju & 0 & 0 & 0 & 0 \\
Tidak Setuju & 0 & 0 & 0 & 0 \\
Setuju & 7 & 77,77 & 77,77 & 77,77 \\
Sangat Setuju & 2 & 22,23 & 22,23 & 22,23 \\
Total & 9 & 100.0 & 100.0 & 100.0 \\
\hline
\end{tabular}

2) Sosialisasi Aplikasi Zoho Form perlu diadakan.

Tabel 2. Perhitungan Sosialisasi

\begin{tabular}{|l|c|c|c|c|}
\hline & Frequency & Percent & $\begin{array}{c}\text { Valid } \\
\text { Percent }\end{array}$ & $\begin{array}{c}\text { Cumulative } \\
\text { Percent }\end{array}$ \\
\hline Valid Sangat Tidak Setuju & 0 & 0 & 0 & 0 \\
Tidak Setuju & 0 & 0 & 0 & 0 \\
Setuju & 6 & 66,66 & 66,66 & 66,66 \\
Sangat Setuju & 3 & 33,34 & 33,34 & 33,34 \\
Total & 9 & 100.0 & 100.0 & 100.0 \\
\hline
\end{tabular}

3) Aplikasi Zoho Mudah Digunakan

Table 3. Aplikasi Zoho

\begin{tabular}{|l|c|c|c|c|}
\hline & Frequency & Percent & $\begin{array}{c}\text { Valid } \\
\text { Percent }\end{array}$ & $\begin{array}{c}\text { Cumulative } \\
\text { Percent }\end{array}$ \\
\hline Valid Sangat Tidak Setuju & 0 & 0 & 0 & 0 \\
Tidak Setuju & 0 & 0 & 0 & 0 \\
Setuju & 9 & 100 & 100 & 100 \\
Sangat Setuju & 0 & 0 & 0 & 0 \\
Total & 9 & 100.0 & 100.0 & 100.0 \\
\hline
\end{tabular}


4) Aplikasi Zoho Form Membantu Mahasiswa Dalam Melakukan Survei

Table 4. Survai Setelah Pelatihan

\begin{tabular}{|l|c|c|c|c|}
\hline & Frequency & Percent & $\begin{array}{c}\text { Valid } \\
\text { Percent }\end{array}$ & $\begin{array}{c}\text { Cumulative } \\
\text { Percent }\end{array}$ \\
\hline Valid Sangat Tidak Setuju & 0 & 0 & 0 & 0 \\
Tidak Setuju & 0 & 0 & 0 & 0 \\
Setuju & 8 & 88,88 & 88,88 & 88,88 \\
Sangat Setuju & 1 & 11,12 & 11,12 & 11,12 \\
Total & 9 & 100.0 & 100.0 & 100.0 \\
\hline
\end{tabular}

5) Setelah Pelatihan Apakah Saudara Bisa Menggunakan Aplikasi Zoho Form

Table 5. Pengunaan Zoho Form

\begin{tabular}{|l|c|c|c|c|}
\hline & Frequency & Percent & $\begin{array}{c}\text { Valid } \\
\text { Percent }\end{array}$ & $\begin{array}{c}\text { Cumulative } \\
\text { Percent }\end{array}$ \\
\hline Valid Sangat Tidak Setuju & 0 & 0 & 0 & 0 \\
Tidak Setuju & 0 & 0 & 0 & 0 \\
Setuju & 8 & 88,88 & 88,88 & 88,88 \\
Sangat Setuju & 1 & 11,12 & 11,12 & 11,12 \\
$\quad$ Total & 9 & 100.0 & 100.0 & 100.0 \\
\hline
\end{tabular}

\section{Kesimpulan}

Dari kegiatan PKM ini semua peserta dapat memahami dan mampu menggunakan aplikasi zoho form dengan baik. Kegiatan pengabdian kepada masyarakat dapat berjalan dengan lancar dan semua peserta memiliki antusiasme yang sangat tinggi terkait dengan pemanfaatan zoho form dalam mendukung pembuatan kuesioner Kegiatan pengabdian kepada masyarakat ini merupakan bentuk yang sangat efektif untuk memberikan tambahan pengetahuan baru dan wawasan dibidang teknologi informasi untuk mendukung penelitian dalam pengumpulan data.

\section{Ucapan Terima Kasih}

Penulis mengucapkan terimakasih kepada Fakultas Ilmu Komputer yang telah mendanai kegiatan pengabdian kepada masyarakat ini, kemudian penulis mengucapkan terimakasih kepada mitra pengabdian Fakultas Ilmu Budaya yang telah bersedia menjadi mitra dalam pelaksanaan pengabdian ini.

\section{Daftar Pustaka}

Amalia, T. "Penggunaan Media Google Form Dalam Evaluasi Pembelajaran Bahasa Arab Maharah Kitabah". Prosiding Konferensi Nasional Bahasa Arab, Vol. 5, No. 5, pp. 318- 323, 2019. 
Asmawan, A. "Analisis kesulitan mahasiswa menyelesaikan skripsi". Jurnal Pendidikan Ilmu Sosial, Vol. 26, No. 2, pp.51-57, 2017.

Batubara, H.H., "Penggunaan Google Form Sebagai Alat Penilaian Kinerja Dosen di Prodi PGMI Uniska Muhammad Arsyad Al Banjari". Al-Bidayah: Jurnal Pendidikan Dasar Islam, Vol.8, No.1, 2016.

Batubara, H. H. \& Noor, D. A., "Workshop Penggunaan Google Form Sebagai Media Evaluasi Pembelajaran Pada Dosen-Dosen Fakultas Studi Islam." Jurnal Pengabdian Al-Ikhlas Universitas Islam Kalimantan Muhammad Arsyad Al Banjary, Vo.2, No. 1, 2017.

E. Nugroho, "Prinsip-prinsip Menyusun Kuesioner". Cetakan Pertama: Universitas rawijaya Press, 2018.

Ihsan, N., Tiwow, V. A., \& Saleh, M. "Pemanfaatan aplikasi google form dalam monitoring kegiatan kuliah pada Program Studi Fisika Universitas Negeri Makassar". In Prosiding Seminar Nasional Fisika PPs Universitas Negeri Makassar, Vol. 2, pp. 2124, 2020.

Maulidiansyah, D., \& Hamdani, H. "Pengembangan Tes Diagnostik Menggunakan Aplikasi Google Form Materi Momentum dan Impuls Untuk Siswa SMA". Jurnal Pendidikan dan Pembelajaran Khatulistiwa, Vol. 7, No. 7, 2018

Muchlis, Christian, A., \& Sari, M.P., "Kuesioner Online Sebagai Media Feedback Terhadap Pelayanan Akademik pada STMIK Prabumulih". Jurnal Eksplora Informatika, Vol. 8, No. 2, pp. 149-157, 2019.

Ritonga, M., Lahmi, A., Rimelfi, R., Bahri, F., \& Bagindo, I. T. "Sosialisasi Pembuatan Soal Melalui Google Form Dalam Meningkatkan Kompetensi Guru PAI". BERNAS: Jurnal Pengabdian Kepada Masyarakat, Vol.1, No. 4, pp. 347-354, 2020.

Roellyana, S., \& Ratih, A.L.,"Peranan Optimisme Terhadap Resiliensi pada Mahasiswa Tingkat Akhir yang Mengerjakan Skripsi." Prosiding Konferensi Nasional Peneliti Muda Psikologi Indonesia Vol. 1, No. 1, pp. 29-37, 2016.

Sianipar, A. Z., "Penggunaan Google Form Sebagai Alat Penilaian Kepuasan Pelayanan Mahasiswa". Journal of Information System, Applied, Management, Accounting and Research, Vol. 3, No. 1, pp. 16-22, 2019.

Yuniarti, R. \& Hartati, W., "Pemantauan Penyebaran Virus Covid-19 Pada Mahasiswa Stia Muhammadiyah Selong Menggunakan Aplikasi Google Form". Jurnal Pengabdian Kepada Masyarakat, Vol. 3, No. 1, pp. 19-28, 2020. 